\title{
ANALYSIS OF RAINY DAYS AND RAINFALL TO LANDSLIDE OCCURRENCE USING LOGISTIC REGRESSION IN PONOROGO EAST JAVA
}

\author{
Dihin Muriyatmoko ${ }^{1}$, Sisca Mayang Phuspa ${ }^{2}$ \\ ${ }^{1}$ Department of Informatics, University of Darussalam Gontor, Indonesia \\ ${ }^{2}$ Department of Occupational Safety and Health, University of Darussalam Gontor, Indonesia \\ Email : dihin@unida.gontor.ac.id, siscamayang@unida.gontor.ac.id
}

Received: 29 July 2018/Revised: 10 August 2018/Accepted: 18 August 2018/Published online: 28 August 2018

\begin{abstract}
Referred to data of Badan Nasional Penanggulangan Bencana (BNPB) and Kementerian Kesehatan Republik Indonesia (Kemenkes RI), almost landslide occurrence in Ponorogo always starts with high-intensity rain. This research aimed to determine simultaneously correlation and partial assessment impact of rainy days every month and monthly rainfall toward landslide occurrence in Ponorogo using logistic regression. The data collection was conducted through Badan Pusat Statistik (BPS) in the book of Ponorogo Regency in Figure on 2012 to 2016. The existing data shows that in sixty months have been twenty-six times landslides occurrence in Ponorogo districts. The data statistically analyzed in simultaneous proves that contribution of rainy days and rainfall to landslide were included adequate correlation (Nagelkerke R Square $=25.4 \%$ and Cox \& Snell R Square $=36.9 \%$ ) and in partial test proves that rainy days have significant impact $($ sig. $=0.024)$ and rainfall does not significant impact (sig. $=0.291)(\alpha=0.05)$ to landslide occurrence in Ponorogo regency. The rainy days per month were abled applied to predict for possible landslide elsewhere.
\end{abstract}

Keywords: rainy days, rainfall, landslide, Ponorogo, logistic regression

\section{Introduction}

Ponorogo Regency is an area in East Java Province who are in a position $200 \mathrm{~km}$ northwest province capital, and $800 \mathrm{~km}$ to the capital city of Indonesia. The area of 1.371 .78 $\mathrm{km}^{2}$ is divided in 21 district that consists of 307 villages. Ponorogo Regency topography varies from lowlands to mountains. Based on existing data, a large district that is $79 \%$ Ponorogo situated at an altitude of fewer than $500 \mathrm{~m}$ above sea level, $14.4 \%$ are between 500 and $700 \mathrm{~m}$ above sea level and the remaining 5.9\% is at the height of the above $700 \mathrm{~m}$ (Badan Perencanaan Pembangunan Daerah Ponorogo, 2013).

Based on the location of topography, climate, and rainfall, Ponorogo regency including areas that are often categorized landslides, especially in the hills and mountains (Yuniarta, Saido, \& Purwana, 2015)of which there are in five districts that is Ngrayun, Slahung, Pudhak, Pulung, and Ngebel. According to data from BNPB and Kemenkes RI from 
2012 to 2016, Ngrayun district was ranked the highest with nine times the landslide, Slahung with five times, Ngebel four times and the last place is Pudhak and Pulung with twice the landslide occurred. Almost all landslide events always start with rainfall in high intensity or rain for more than a day(Badan Nasional Penanggulangan Bencana, 2018; Kementerian Kesehatan Republik Indonesia, 2018).

Factors of rainy days and rainfall are also the ultimate set to be the cause of the occurrence of the landslide by Ubeku and Okeke (Ubechu \& Okeke, 2017), as well as Paimin a Geoscientist who gave a statement that $25 \%$ of landslide factors are caused by rainy days for three days. (Paimin, Sukresno, \& Pramono, 2009), the Department of Public Works also makes one of the fourteen factors that cause landslides is rainfall (Departemen Pekerjaan Umum, 2007), the book of Disaster Risks Indonesia also makes one of the four factors that cause landslides is rainfall (Amri et al., 2016). This study examines the extent to which the simultaneous correlation of rainy days every month and monthly rainfall on the occurrence of landslides in Ponorogo and the impact of rainy days every month and monthly rainfall on landslides in Ponorogo using logistic regression.

These are some studies related to landslides and logistic regression i.e, the first is the results perform that landslides terrace dramatically from 1946 to 2012 inthe capture area. The nearness and overlapping of human development with landslides terraced. However,the logistic regression results prove that variation in sensitivity to landslides was due to natural causes, with the exclusion of historical deforestation and recentlyestablished road systems. Accordingly, well-recoveredhistoricalwoodland sites might presently be landslide-prone areas(Y. C. Chuang \& Shiu, 2018), second in Ambon Indonesia, eight landslide causative factors were respected in the landslide sensitivityevaluation. The causative factors were height, slope angle, slope aspect, closeness to stream network, lithology, the solidity of geological boundaries, closenessto faults, and closenessto the road network. The output sensitivitymaps were reclassified into five categorize ranging from very low to very high sensitivity using Jenks natural breaksmethod. Twenty percent of allmapped landslideswere used as the legalization of the sensitivitymodels. The legalization and the accuracy of each modelwere examined by calculating areas under recipient operating characteristic curves (ROCs), andthe areasnether the curve (AUC) for the success rate curves of FR, LR, and ANN were $0.688,0.687$, and 0.734 , severally. The AUC for the prediction rate curve of FR, LR, and ANN were 0.668, 0.667, and 0.717, respectively (Aditian, Kubota, \& Shinohara, 2018), the third is twelve landslide causative factors (namely, slope, slope aspect, highness, curvature, profile arch, plan arch, slope length, topographic dampness index, gap to river, gap 
to road, gap to fault and yearly maximum 24- and 48-h rainfalls) were used in this landslide sensitivity analysis. These models were applied to the Kaoping River basin in Southwestern Taiwan to rate its show. Landslide inventory maps from 2008 to 2011 were congregated. The results prove that the RBF-SVM model makes better the logistic regression in the study area (Lin, Chang, Huang, \& Ho, 2017).

\section{The Methods}

Logistic regression is a method of statistical analysis to describe the relationship between response variables (dependent variable) which has two or more categories with one or more explanatory variables (independent variable) scale or interval (Hosmer \& Lemeshow, 2005). Logistic regression is a nonlinear regression, used to explain the relationship between $\mathrm{X}$ and $\mathrm{Y}$ which is nonlinear, $\mathrm{Y}$-dislocated abnormality, diversity of non-constant response unexplained by ordinary linear regression model (Agresti, 1996).

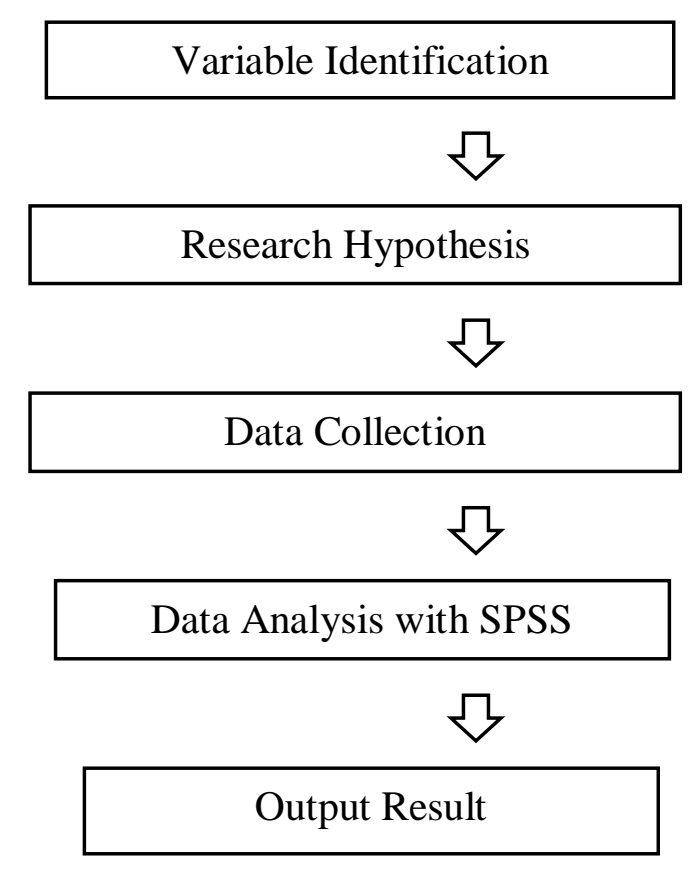

Figure 1. Research method with regression logistic

\subsection{Variable Identification}

Independent variable is landslide occurrence and the dependent variable is rainy days every month and rainfall every month

\subsection{Research Hypothesis}


1. Any simulant correlation between rainy days every month and rainfall every month to landslide occurrence

2. Impact between rainy days every month to landslide occurrence

3. Impact between rainfall every month to landslide occurrence

\subsection{Data collection}

This data was taken on five years from Ponorogo in Figure since 2012 to 2016 by Ponorogo Regional Development Planning Agencyand Central Bureau of Statistics (Badan Perencanaan Pembangunan Daerah Ponorogo, 2013, 2014, Badan Pusat Statistik Kabupaten Ponorogo, 2015a, 2015b, 2016), Ministry of Health of the Republic of Indonesia (Kementerian Kesehatan Republik Indonesia, 2018) and BPBD (Badan Nasional Penanggulangan Bencana, 2018).

Table 1. Data of rainy days every month, rainfall every month and landslide occurred status in 2012-2016 at Ponorogo regency

\begin{tabular}{|c|c|c|c|c|c|c|c|c|c|c|c|}
\hline No. & Years & Month & $\begin{array}{l}\text { Rainy } \\
\text { Days } \\
\text { Every } \\
\text { Month }\end{array}$ & $\begin{array}{l}\text { Rainfall } \\
\text { Every } \\
\text { Month }\end{array}$ & $\begin{array}{l}\text { Landslide } \\
\text { Status }\end{array}$ & No. & Years & Month & $\begin{array}{l}\text { Rainy } \\
\text { Days } \\
\text { Every } \\
\text { Month }\end{array}$ & $\begin{array}{c}\text { Rainfall } \\
\text { Every } \\
\text { Month }\end{array}$ & $\begin{array}{c}\text { Landslide } \\
\text { Status }\end{array}$ \\
\hline 1 & 2012 & 1 & 21 & 15 & No & 31 & 2014 & 7 & 2 & 7 & No \\
\hline 2 & 2012 & 2 & 13 & 16 & Yes & 32 & 2014 & 8 & 0 & 8 & No \\
\hline 3 & 2012 & 3 & 16 & 12 & No & 33 & 2014 & 9 & 0 & 0 & No \\
\hline 4 & 2012 & 4 & 12 & 17 & No & 34 & 2014 & 10 & 0 & 12 & No \\
\hline 5 & 2012 & 5 & 7 & 15 & No & 35 & 2014 & 11 & 13 & 16 & No \\
\hline 6 & 2012 & 6 & 2 & 7 & No & 36 & 2014 & 12 & 18 & 19 & Yes \\
\hline 7 & 2012 & 7 & 1 & 3 & No & 37 & 2015 & 1 & 14 & 8 & No \\
\hline 8 & 2012 & 8 & 0 & 0 & No & 38 & 2015 & 2 & 16 & 13 & Yes \\
\hline 9 & 2012 & 9 & 1 & 4 & No & 39 & 2015 & 3 & 20 & 12 & Yes \\
\hline 10 & 2012 & 10 & 3 & 11 & No & 40 & 2015 & 4 & 15 & 11 & Yes \\
\hline 11 & 2012 & 11 & 11 & 19 & No & 41 & 2015 & 5 & 4 & 1 & No \\
\hline 12 & 2012 & 12 & 23 & 17 & No & 42 & 2015 & 6 & 1 & 11 & No \\
\hline 13 & 2013 & 1 & 23 & 17 & No & 43 & 2015 & 7 & 0 & 0 & No \\
\hline 14 & 2013 & 2 & 18 & 19 & No & 44 & 2015 & 8 & 0 & 0 & No \\
\hline 15 & 2013 & 3 & 15 & 14 & No & 45 & 2015 & 9 & 0 & 0 & No \\
\hline 16 & 2013 & 4 & 13 & 19 & Yes & 46 & 2015 & 10 & 0 & 2 & No \\
\hline 17 & 2013 & 5 & 15 & 12 & Yes & 47 & 2015 & 11 & 8 & 4 & No \\
\hline 18 & 2013 & 6 & 12 & 13 & Yes & 48 & 2015 & 12 & 16 & 10 & No \\
\hline 19 & 2013 & 7 & 8 & 11 & No & 49 & 2016 & 1 & 16 & 17 & No \\
\hline 20 & 2013 & 8 & 0 & 0 & No & 50 & 2016 & 2 & 20 & 19 & Yes \\
\hline 21 & 2013 & 9 & 0 & 0 & No & 51 & 2016 & 3 & 16 & 21 & Yes \\
\hline 22 & 2013 & 10 & 3 & 17 & No & 52 & 2016 & 4 & 17 & 19 & Yes \\
\hline
\end{tabular}




\begin{tabular}{llllllllllll}
\hline 23 & 2013 & 11 & 13 & 18 & No & 53 & 2016 & 5 & 12 & 14 & Yes \\
\hline 24 & 2013 & 12 & 19 & 19 & No & 54 & 2016 & 6 & 11 & 14 & No \\
\hline 25 & 2014 & 1 & 18 & 17 & Yes & 55 & 2016 & 7 & 6 & 9 & No \\
\hline 26 & 2014 & 2 & 14 & 12 & No & 56 & 2016 & 8 & 5 & 9 & No \\
\hline 27 & 2014 & 3 & 13 & 17 & No & 57 & 2016 & 9 & 13 & 21 & Yes \\
\hline 28 & 2014 & 4 & 11 & 15 & No & 58 & 2016 & 10 & 15 & 17 & No \\
\hline 29 & 2014 & 5 & 6 & 14 & No & 59 & 2016 & 11 & 23 & 22 & Yes \\
\hline 30 & 2014 & 6 & 4 & 22 & No & 60 & 2016 & 12 & 16 & 12 & Yes \\
\hline
\end{tabular}

\subsection{Data Analysis with SPSS}



Figure 2. Data Analysis method with regression logistic using SPSS

Figure 2 describes the logistic regression stage i.e. data validation test is used to know that data is valid or not, variable category naming is used to know the code of the landslide occurs or not, the properness model test is used for sufficiently explained the data (Goodness of fit), the significant test is used to know the correlation value of dependent variables to independent variable, the accuracy classification test is used for measure precision prediction in this study, and the last partial test is used to prove the significance value of dependent variables to independent variable. The statistic of logistic regression was produced the chi-square value that is used to check the correlation of rainy days and rainfall toward landslide occurrence. The accepted criteria of rainy days and rainfall to landslide occurrence can be seen if the chi-square value is lower than chi-square table.

\subsection{Output Result}

The output details referred to Figure 2 were shown in the result and discussion section. 


\section{Results and Discussion}

Here are the results of calculations using logistic regression using SPSS tools (Reed \& Wu, 2013)

\subsection{Data Validation Test}

Table 2. Case Processing Summary

\begin{tabular}{cccc}
\hline \multicolumn{4}{c}{ Case Processing Summary } \\
\hline \multicolumn{2}{c}{ Unweighted Cases $^{\mathrm{a}}$} & $\mathrm{N}$ & Percent \\
\hline \multirow{2}{*}{ Selected Cases } & Included in Analysis $^{\text {Missing Cases }}$ & 60 & 100.0 \\
\cline { 2 - 4 } & Total & 0 & .0 \\
\cline { 2 - 4 } & 60 & 100.0 \\
\hline Unselected Cases & 0 & .0 \\
\hline Total & 60 & 100.0
\end{tabular}

Referred to table 2 , the sixty data is valid and no missing cases.

\subsection{Variable Category Naming}

Table 3. Dependent Variable Encoding

\begin{tabular}{lr}
\hline \multicolumn{2}{c}{ Dependent Variable Encoding } \\
\hline Original Value & Internal Value \\
\hline No landslide occurred & 0 \\
\hline Landslide occurred & 1 \\
\hline
\end{tabular}

Referred to table 3. Azero value indicates that is no landslides are occurring, and one value indicates that landslide occurred.

\subsection{Properness Model Test}

Table 4. Omnibus Tests of Model Coefficients

\begin{tabular}{llllr}
\hline \multicolumn{5}{c}{ Omnibus Tests of Model Coefficients } \\
\hline \multirow{2}{*}{ Step 1 } & \multicolumn{1}{l}{ Chi-square } & df & \multicolumn{1}{c}{ Sig. } \\
\cline { 2 - 5 } & Step & 17.552 & 2 & .000 \\
\cline { 2 - 5 } & Block & 17.552 & 2 & .000 \\
\cline { 2 - 5 } & Model & 17.552 & 2 & .000 \\
\hline
\end{tabular}

The correlation between $\mathrm{X} 1$ and $\mathrm{X} 2$ to $\mathrm{Y}$, Chi-Square technique obtained Chi-Square value 17.552 with $\operatorname{Sig}$ value $0.000<0.05$, it means together rainy days (X1) and rainfall (X2) associated with a landslide (Y).

Omnibus Tests:

$\mathrm{H} 0=$ variables $\mathrm{x} 1$ and $\mathrm{x} 2$ do not significantly affect $\mathrm{Y}$

$\mathrm{H} 1=$ at least one between $\mathrm{x} 1$ and $\mathrm{x} 2$ significantly affect to $\mathrm{y}$ 
Test criteria: $\mathrm{H} 0$ is rejected if sig value $<0.05$, or chi-square value $>$ chi-square table (5.99) Referred to Table 4. The output can be seen that significant $=0.000$, it means less than 0.05 and chi-square value is 17.552 , it means chi-square value is higher than chi-square table.

Decision: H0 rejected

Conclusion: the value of chi-square $=17.552$ with significant value or $\mathrm{p}$-value $=0.000$ means with $95 \%$ confidence level, there is at least one free variable $(x 1, x 2)$ that influence on the dependent variable, so the model can be used for further analysis

Table 5. Hosmer and Lemeshow Test

\begin{tabular}{cccc}
\hline \multicolumn{4}{c}{ Hosmer and Lemeshow Test } \\
\hline Step & Chi-square & df & Sig. \\
\hline 1 & 6.023 & 8 & .645 \\
\hline
\end{tabular}

The probability of $0.645>0.05$, meaning that the binary regression model is suitable for further analysis since there is no significant difference between the predicted classification and the observed classification.

Hosmer and Lemeshow Test:

$\mathrm{H} 0=$ The model has sufficiently explained the data (Goodness of fit)

$\mathrm{H} 1=$ Model is not enough to explain data

Test criteria:

$\mathrm{H} 0$ accepted If the p-value or significance $>0.05$

Referred to Table 5. has a significance value of $0.645>0.05$, it means that the significance value is greater than 0.05 .

Decision: H0 accepted

Conclusion: the model has sufficiently explained the data (goodness of fit).

\subsection{Significance Test}

Table 6. Model Summary

\begin{tabular}{cccc}
\hline \multicolumn{3}{c}{ Model Summary } \\
\hline Step & $\mathbf{- 2}$ Log likelihoods & Cox \& Snell R Square & Nagelkerke R Square \\
\hline 1 & $52.038 \mathrm{a}$ & .254 & .369 \\
\hline
\end{tabular}

Referred to table 7 indicates that the coefficient determinant of logistic regression that is 0,369 so it can be concluded that the contribution of variable $\mathrm{X} 1$ and $\mathrm{X} 2$ to $\mathrm{Y}$ is equal to $37 \%$

4. Accurate Classification Test (Percentage Correct)

Table 7. Classification

\section{Classification Table $^{\mathrm{a}}$




\begin{tabular}{llllll}
\hline & & \multicolumn{2}{l}{ Landslide occurred } & \multirow{2}{*}{ Percentage Correct } \\
\cline { 3 - 5 } & & No & Yes & \\
\hline \multirow{2}{*}{ Step 1 } & $\begin{array}{l}\text { Landslide } \\
\text { occurred }\end{array}$ & No & 39 & 5 & 88.6 \\
\cline { 2 - 5 } & Yes & 9 & 7 & 43.8 \\
\hline
\end{tabular}

Referred to table 7 indicates thatprecision prediction in this study is $76.7 \%$.

\subsection{Partial Test}

Table 8. Variable in the Equation

\begin{tabular}{ccc|c|c|c|c|c}
\hline \multicolumn{7}{c}{ Variables in the Equation } \\
\hline & B & S.E. & Wald & df & Sig. & $\operatorname{Exp}(\mathbf{B})$ \\
\hline \multirow{2}{*}{ Step 1a } & Rainy Days & .169 & .075 & 5.121 & 1 & .024 & 1.184 \\
\cline { 2 - 9 } & Rainfall & .096 & .091 & 1.114 & 1 & .291 & 1.101 \\
\cline { 2 - 9 } & Constant & -4.498 & 1.440 & 9.762 & 1 & .002 & .011 \\
\hline
\end{tabular}

The partial test shows that only X2 is significant because of the value of Sig 0.024 $<0.05$, while $\mathrm{X} 2$ significant $0.291>0.05$ means that alone $\mathrm{X} 1$ has no significant effect on $\mathrm{Y}$. A partial test of rainy days every month:

$\mathrm{H} 0=0$, the variable of rainy days does not significantly affect the landslide

$\mathrm{H} 1 \neq 0$, the variable of rainy day significantly affects the landslide

Test criteria:

$\mathrm{HO}$ is rejected if significance value $<0.05$

Decision: $\mathrm{H} 0$ is rejected because significance value $=0.24$

Conclusion: rainy days have significantly affected the landslide

A partial test of rainfall every month:

$\mathrm{HO}=0$, the variable of rainfall does not significantly affect to landslide occurred

$\mathrm{H} 1 \neq 0$, the variable of rainfall significantly affects the landslide

Test criteria:

$\mathrm{H} 0$ is rejected if significance value $<0.05$

Decision: $\mathrm{H} 0$ is accepted because significance value $=0.291$

Conclusion: rainfall does not have significantly affect to landslide occurred

Referred to table 2 to table 8 , prove that in Ponorogo regency the factor of rainy days every month have significantly affectedto the landslide occurred and rainfall every month does not have significantly affected to the landslide occurred. So, for the next step we can 
discuss that the numberof rainy days every month can be used to predict landslide occurs in Ponorogoand to analysis of landslide can use the others methods besides logistic regression for example artificial neural network (Logar, Turk, Marsden, \& Ambrožič, 2017), support vector machine (Y. Chuang \& Shiu, 2018), artificial neural networks (ANNs), boosted regression tree (BRT), classification and regression trees (CART), generalized linear model (GLM), generalized additive model (GAM), multivariate adaptive regression splines (MARS), naïve Bayes (NB), quadratic discriminant analysis (QDA), random forest (RF), and support vector machines (SVM) (Pourghasemi \& Rahmati, 2018).

\section{Conclusion}

The data statistically from Ponorogo regency that analyzed using logistic regression method in simultaneous proves that contribution of rainy days and rainfall to landslide were included adequate correlation (Nagelkerke R Square $=25.4 \%$ and Cox \& Snell R Square $=$ $36.9 \%)$ and in partial test proves that rainy days have significant impact (sig. $=0.024)$ and rainfall does not significant impact $($ sig. $=0.291)(\alpha=0.05)$ to landslide occurrencein Ponorogo regency. For the next research, the rainy days per month were abled applied to predict for possible landslide elsewhere and landslide analized can used others algoriltm beside linear regression such as artificial neural network, support vector machine, boosted regression tree, generalized linear regression, etc.

\section{Acknowledgement}

We would like to thank the Ministry of Research and Higher Education for the support of research grants in 2017 , so that this research can work well.

\section{References}

Aditian, A., Kubota, T., \& Shinohara, Y. (2018). Geomorphology Comparison of GIS-based landslide susceptibility models using frequency ratio, logistic regression, and arti fi cial neural network in a tertiary region of Ambon , Indonesia. Geomorphology Journal, 318, 101-111. https://doi.org/10.1016/j.geomorph.2018.06.006

Agresti, A. (1996). An Introduction to Categorical Data Analysis. Wiley. https://doi.org/10.1002/0470114754

Amri, M. R., Yulianti, G., Yunus, R., Wiguna, S., Adi, A. W., Ichwana, A. N., ... Septian, R. T. (2016). Risiko Bencana Indonesia. Jakarta: Badan Nasional Penanggulangan 
Bencana.

Badan Nasional Penanggulangan Bencana. (2018). Data Pantauan Bencana. Retrieved June 21, 2018, from http://geospasial.bnpb.go.id/pantauanbencana/data/index.php Badan Perencanaan Pembangunan Daerah Ponorogo. (2013). Pembangunan Ponorogo Dalam Angka 2013. Ponorogo. Retrieved from https://ponorogokab.bps.go.id/publication/

Badan Perencanaan Pembangunan Daerah Ponorogo. (2014). Pembangunan Ponorogo Dalam Angka 2014. Ponorogo. Retrieved from https://ponorogokab.bps.go.id/publication

Badan Pusat Statistik Kabupaten Ponorogo. (2015a). Ponorogo Dalam angka 2015. Ponorogo. Retrieved from https://ponorogokab.bps.go.id/publication

Badan Pusat Statistik Kabupaten Ponorogo. (2015b). Ponorogo Dalam angka 2017. Ponorogo. Retrieved from https://ponorogokab.bps.go.id/publication

Badan Pusat Statistik Kabupaten Ponorogo. (2016). Ponorogo Dalam angka 2016. Ponorogo. Retrieved from https://ponorogokab.bps.go.id/publication

Chuang, Y. C., \& Shiu, Y. S. (2018). Relationship between landslides and mountain development-Integrating geospatial statistics and a new long-term database. Science of the Total Environment Journal, 622-623, 1265-1276.

https://doi.org/10.1016/j.scitotenv.2017.12.039

Chuang, Y., \& Shiu, Y. (2018). Science of the Total Environment Relationship between landslides and mountain development - Integrating geospatial statistics and a new long-term database. Science of the Total Environment Journal, 622-623, 1265-1276. https://doi.org/10.1016/j.scitotenv.2017.12.039

Departemen Pekerjaan Umum. Pedoman Penataan Ruang Kawasan Rawan Bencana Longsor, Pub. L. No. 22 /PRT/M/2007, 148 (2007). Indonesia: Menteri Pekerjaan Umum Republik Indonesia. Retrieved from landspatial.bappenas.go.id/komponen/peraturan/the_file/permen22_2007.pdf\%0A

Hosmer, D. W., \& Lemeshow, S. (2005). Multiple Logistic Regression. In Applied Logistic Regression (pp. 31-46). Hoboken, NJ, USA: John Wiley \& Sons, Inc. https://doi.org/10.1002/0471722146.ch2

Kementerian Kesehatan Republik Indonesia. (2018). Pusat Krisis Kesehatan Kementerian Kesehatan Republik Indonesia. Retrieved June 11, 2018, from http://pusatkrisis.kemkes.go.id/

Lin, G., Chang, M., Huang, Y., \& Ho, J. (2017). Assessment of susceptibility to rainfall- 
induced landslides using improved self-organizing linear output map, support vector machine, and logistic regression. Engineering Geology Journal, 224(May), 62-74. https://doi.org/10.1016/j.enggeo.2017.05.009

Logar, J., Turk, G., Marsden, P., \& Ambrožič, T. (2017). Prediction of rainfall induced landslide movements by artificial neural networks. Journal of Natural Hazards and Earth System Sciences Discussions, (July), 1-18. https://doi.org/10.5194/nhess-2017253

Paimin, Sukresno, \& Pramono, I. B. (2009). Teknik Mitigasi Banjir dan Tanah Longsor. (A. N. Ginting, Ed.). Balikpapan: Tropenbos International Indonesia Programme. Retrieved from www.tropenbos.org

Pourghasemi, H. R., \& Rahmati, O. (2018). Prediction of the landslide susceptibility: Which algorithm, which precision? Catena Journal, 162(November), 177-192. https://doi.org/10.1016/j.catena.2017.11.022

Reed, P., \& Wu, Y. (2013). Journal of Fluency Disorders Logistic regression for risk factor modelling in stuttering research \&. Journal of Fluency Disorders, 38(2), 88-101. https://doi.org/10.1016/j.jfludis.2012.09.003

Ubechu, B. O., \& Okeke, O. . (2017). Landslide: Causes, Effects and Control. International Journal of Current Multidisciplinary Studies, 3(03), 647-663.

Yuniarta, H., Saido, A. P., \& Purwana, Y. M. (2015). Kerawanan Bencana Tanah Longsor Kabupaten Ponorogo. Jurnal Matriks Teknik Sipil, 3(1), 194-201. 